DOI: $10.17951 /$ rh.2018.46.351-363

\author{
Marek Woźniak \\ (Uniwersytet Marii Curie-Skłodowskiej w Lublinie) \\ https://orcid.org/0000-0002-1746-0703
}

\title{
A jeśli prawda nie istnieje..., czyli o roli wartości w historiografii (w obronie prawdy historycznej)
}

\author{
What if the Truth does not Exist... or the Role of Values in Historiography \\ (in Defense of Historical Truth)
}

\begin{abstract}
STRESZCZENIE
W artykule próbuję odpowiedzieć na pytania o rolę/funkcje wartości w pisarstwie historycznym, o ich miejsce w narracji oraz zastanawiam się, czy jest/lub jak jest możliwa historiografia wolna od prawdy (historycznej), będącej konsekwencją nie tyle procesu dochodzenia do niej, ale raczej opartej na zakładanej przez historyka wizji świata i człowieka/ światooglądu, ideale nauki oraz preferowanej (wyznawanej) aksjologii. Zakładam zatem, odwołując się przede wszystkim do socjologii wiedzy i narzędzi oferowanych przez konstruktywistyczny model poznania, że stosunek do prawdy/wartości w badaniach historycznych realizuje się w trzech (przynajmniej) postawach, a mianowicie: konserwatywnej, liberalnej oraz pragmatycznej. Przesądy obecne w każdej z nich decydują o stosunku do prawdy/wartości oraz pełnionych przez nie funkcji w procesach poznawczych. $Z$ przedstawionych obserwacji wynika bowiem, że prawda/prawdy/wartości okazują się w zasadzie retorycznymi argumentami wykorzystywanymi w sporach między konkurencyjnymi wizjami/wizerunkami przeszłości/świata. Ich funkcje sprowadza się do umacniania/ kreowania autorytetu Historyka, a w konsekwencji do prowadzenia (właściwej) polityki historycznej.
\end{abstract}

Słowa kluczowe: prawda, wartości, historiografia, badanie historyczne, proces badawczy, ideał nauki historycznej

\section{ZAŁOŻENIA}

- Przedmiotem mojego zainteresowania nie będzie prawda (historyczna), nie będę próbował odpowiedzieć na pytanie/a czym jest, jak prawdę się definiowało/definiuje, czy jest/nie jest obecna w dyskursie histo- 
rycznym/narracji historycznej, czy można/nie można do niej dotrzeć, w jaki sposób ją odkryć/nie odkryć lub tylko się do niej zbliżyć.

- Nie będę również dokonywał rozróżnienia między światem wartości historyka a wartościami przypisywanymi przeszłości/historii/historiografii - choć mogłoby okazać się to interesujące, a może nawet niezwykle płodne - zaznaczę jedynie, że zdając sobie sprawę z faktu, iż są to różne porządki, pozostaję $\mathrm{w}$ przekonaniu, że są one na tyle uniwersalne, w tym sensie przynajmniej, że przypisuje się je lub obdarza nimi tak przeszłość, jak historiografię i samego historyka..., co ostatecznie wychodzi naprzeciw mojej głębokiej wierze w to, że historyk jest częścią historii...

- Interesować mnie będzie natomiast to, czemu służy deklaracja o jej obecności/nieobecności, skąd berze się potrzeba takiej deklaracji, czy i jak obecność/nieobecność prawdy w deklaracjach/celach zmienia historię/historiografię/jej funkcje.

- W jakiejś mierze będę próbował także odpowiedzieć na pytania o to, czy/do czego prawda (historyczna) jest potrzebna historykom, czy społeczeństwo/czytelnik/odbiorca potrzebuje/nie potrzebuje prawdy (o przeszłości), czy/ewentualnie jaki historia bez prawdy ma sens, czym się prawdę zastępuje/czym można ją zastąpić, czy/jak prawda nadaje sens/sensy/znaczenie/znaczenia przeszłości/historiografii, czy i ewentualnie jak uciec od prawdy (historycznej).

- Sama prawda będzie zatem pretekstem do refleksji nad rolą wartości, które przyświecaja/kierują postępowaniem badawczym historyków...

Zacznijmy od tego, że choć prawda (historyczna) rzadko staje się przedmiotem refleksji (namysłu) - bywa natomiast przedmiotem dyskusji - historyków-praktyków, to jej obecność (lub brak) w narracji okazuje się kryterium oceny treści. Trudno jednak nie odnieść wrażenia, że nieczęsto rodzi to potrzebę uzasadniania innego rodzaju niż tej związanej z wymogami warsztatu i opartej na nim uczciwości „naukowej”" . Uczciwość/rzetelność, a ostatecznie także warsztat decydują zatem o uznaniu 'prawdy' za warunek jakości wiedzy, choć podobnie jak ona sama, będąc wartościami, nie znajdują swego uzasadnienia w 'rzeczywistości/fakcie', ale raczej w kulturze (świecie kultury), która czyni z nich elementy/komponenty (naszego) ludzkiego myślenia o otaczającej nas „rzeczywistości”. Jako takie zaś charakteryzuje je raczej przygodność i lokalność (tymczasowość/ historyczność) niż niezbywalność i trwałość. Z tezą tą można oczywiście

1 Zazwyczaj wystarczy uznanie/założenie, że prawda jest koniecznym i niezbywalnym warunkiem jakości. 
polemizować, wskazując je np. jako wartości ‘właściwe naturze ludzkiej’, choć zdrowy rozsądek i nawet powierzchowna obserwacja podpowiada, że być może z naturą (człowieka) wiele wspólnego nie mają. Nie znaczy to oczywiście, że można z góry uznać, iż ich nieobecność/obecność nie przesądza/przesądza o „naturze ludzkiej”. Można się natomiast zastanawiać, czy nie decyduje (obecność/nieobecność) o przynależności, przez co stają się one - w pewnym sensie - kryteriami wykluczenia. Ich obecność a w efekcie także prawdy - jest zatem konsekwencją pewnych (tymczasowych?) standardów wypracowanych w ramach kultury, a nie wymogiem/ elementem natury. I choć nietrudno zgodzić się z założeniem (aksjomatem właściwie), że stanowią one istotny składnik kultury, to ich obecność w procesach poznawania (przeszłości) nie jest już tak bezdyskusyjna. Łatwo bowiem wyobrazić sobie sytuację, że to nie 'prawda' (uczciwość/ rzetelność), ale pragmatyka życia społecznego ${ }^{2}$ determinuje formułowane przez historyków obrazy przeszłości. Nie znaczy to jednak, że możemy uznać ja/je za niepotrzebna/e czy wręcz niepożądana/e - wskazuję jedynie, że obrazy te $\mathrm{w}$ jakiejś mierze są budowane na podstawie nie tyle faktów, co wartości. Sam problem odróżnienia (faktu od wartości) pozostawiam tu bez rozstrzygnięcia, uznając jedynie, że fakty znajdują swoje uzasadnienie $\mathrm{w}$ materiale faktograficznym, wartości zaś - źródła mogą się do nich odwoływać (moim celem była prawda...) - są obecne przede wszystkim w rzeczywistości pomyślanej, w świecie myśli/idei, choć mogą wpływać na (kształtować) tę/ten 'materialna/materialny'4.

Umówmy się (na chwile), że prawda (historyczna) nie istnieje, że w historii nie chodzi zatem o prawdę (historyczna), $i \dot{z}$ e prawda jest jedynie argumentem/ instrumentem, który pełni w ramach badań historycznych określonalokreślone (przez kulturę/środowisko) rolęlfunkcje.

Przyjmując powyższe założenie, możemy dostrzec trzy (choć ostatecznie, jak się okaże, cztery) możliwe postawy przyjmowane wobec zawartej w nim tezy, a w konsekwencji także wobec roli/funkcji prawdy/wartości, jaką odgrywają w historiografii/badaniu historycznym. Postawa pierwsza, którą możemy określić jako konserwatywną, wyraża się w przekonaniu, że - niezależnie od argumentów przywoływanych dla uzasadnienia jej nieobecności - prawda istnieje. Postawę tę charakteryzuje trwanie na stanowisku głoszącym konieczność traktowania prawdy jako zasadniczego celu/ wartości badań historycznych i potrzebę podejmowania prób jego osią-

\footnotetext{
2 Ideologia, pragnienie władzy, ambicje.

3 Nieco upraszczając problem, zakładam, że źródła odzwierciedlają horyzont poznawczy Autora, a w tym sensie także jego świat wartości.

4 Por. M. Woźniak, Od prawdy historycznej do sensu dziejów. Wartości a obraz przeszłości, w: Aksjologiczne aspekty dyskursu humanistycznego, Chełm 2012.
} 
gnięcia/dotarcia do, ale także przeświadczenie/pewność, że jest to - choć w kwestii dróg jego osiągnięcia pojawiają się zdania rozbieżne - możliwe (w ramach procesów poznawania przeszłości). Jest przy tym oczywiste, że postawa ta prawdę/wartości traktuje jako niezbywalny/konieczny element badań historycznych (procesów poznawania przeszłości) oraz kryterium oceny narracji/dyskursu historycznego/obrazu przeszłości. Ocena ta wyrażana jest w twierdzeniach, np.: to nie ma nic wspólnego z prawda historyczna; to catkowicie fatszywy opis przebiegu wydarzeń/tego co się wydarzyło; mamy tu do czynienia z nieprawdziwym obrazem przeszłości; Autor całkowicie rozmija sie z prawdą. Charakterystyczną cechą tej postawy staje się jednocześnie nie tylko przywiązanie do klasycznego/tradycyjnego ideału nauki (historycznej) ${ }^{5}$, ale przede wszystkim do obecnych w nim przeświadczeń/założeń. Zaliczyć do nich możemy przede wszystkim przekonanie o istnieniu niezależnego od historyka/badacza przedmiotu badań, który choć (już) nieobecny istnieje i czeka na odkrycie. Kluczowa w tej postawie jest jednak wiara w moc źródła (historycznego). Wiara ta pociagga za sobą przekonanie, że źródło odbija/ odzwierciedla przeszłość, a w najgorszym przypadku jest jej fragmentem. To właśnie wiara w źródło, jego możliwości sprawcze, wychodzi naprzeciw lub jest komplementarna wobec przekonania o konieczności/możliwości odkrycia/dotarcia do prawdy.

W takiej sytuacji nietrudno uznać, że prawda staje się przedmiotem śledztwa, źródła zaś materiałem dowodowym pomagającym ją sfalsyfikować lub potwierdzić. Paradoksalnie jednak kontekst odkrycia przestaje odgrywać istotną rolę w poznaniu (przeszłej rzeczywistości), a kluczową rolę zdaje się pełnić kontekst uzasadnienia. A w takiej perspektywie ważne okazują się nie te argumenty, które dowodzą 'prawdy' czy konieczności dotarcia do niej, ale te, które mają wystarczającą moc perswazyjną, żeby nas do którejś z możliwych prawd przekonaćc. W efekcie do prawdy się nie „dociera" ani jej nie „odkrywa”, ale jedynie poszukuje się argumentów - choć przy okazji sama często staje się argumentem - dla jej potwierdzenia. W konsekwencji rodzi się przekonanie, że prawda (historyczna) jest nie tyle rezultatem poznania (historycznego), co jego przyczyną (lub uzasadnieniem właśnie) - lub mówiąc inaczej: jest nie tyle efektem, co punktem wyjścia. Oczywiście niesie to za sobą określone skutki dla procesu poznawania przeszłości. Jeśli spojrzymy bowiem na kategorię prawdy

5 Zob. J. Pomorski, Historyk i metodologia, Lublin 1991, szkic trzeci.

6 Paul Valéry twierdził, że przy pomocy "historii możemy uzasadnić wszystko”, co samo z siebie wskazuje, że także (każdą) możliwą lub pożądaną prawdę. Por. P. Valéry, Regards sur le monde actuel, Paris 1931, s. 63-64, za: R. Stobiecki, Historia pod nadzorem: spory o nowy model historii w Polsce (II połowa lat czterdziestych - początek lat pięćdziesiatych), Łódź 1993, s. 13. 
(historycznej) jako przyczynę i uzasadnienie, to może się okazać, że to nie wymogi warsztatu czy standardy nauki determinują treść wiedzy (obraz przeszłości), ale - mające historyczny (lokalny) charakter - wartość/wartości. W moim przekonaniu nie tylko otwiera to drogę do odrzucanego w ramach klasycznego ideału nauki (historycznej) relatywizmu poznawczego, ale przede wszystkim determinuje zarówno proces 'dochodzenia' (do wiedzy), jak i sam status wiedzy konstytuowanej przez historyków. Oparcie tej wiedzy na fundamentach, dla których źródłem jest świat wartości, pozwala patrzeć na obrazy przeszłości z niej wynikające (lub będące jej konsekwencją) jako aksjologicznie motywowane i kulturowo uwarunkowane. I choć obecna w klasycznej koncepcji prawdy „zgodność z rzeczywistością" pozostaje w takiej perspektywie aktualna, to można dyskutować o jej (rzeczywistości) treści, czy mówiąc bardziej ogólnie: pytać o jej ontologiczne przesłanki i umocowanie ${ }^{7}$.

W ramach tej postawy/tego stanowiska funkcje pełnione przez prawdę/wartości w historiografii/poznaniu historycznym są nie tylko gwarantem wypełnienia/wypełniania funkcji, jakie pełni nauka (historyczna) wobec społeczeństwa, ale często funkcje te dubluje, zastępuje bądź utożsamia (w ten sposób otrzymujemy takie konstrukcje, jak m.in.: historia jest nauczycielka życia tylko, jeśli jest prawdziwa; tylko prawda o przeszłości wyzwoli nas z niewiedzy; historia integruje, jeśli jest oparta na prawdzie; prawda historyczna buduje nasza tożsamość; mity historyczne możemy obalić tylko na drodze prawdy/poprzez poznanie prawdy itp.). W takiej sytuacji prawda (historyczna), podobnie jak inne wartości przypisywane zazwyczaj historii, staje się narzędziem, ale i warunkiem realizacji funkcji społecznych identyfikowanych $\mathrm{z}$ historiografią.

$* * *$

Postawa druga - nazwijmy ją liberalną - dostrzega wszystkie te wątpliwości, które (z natury) wpisane są w założenia/przeświadczenia stanowiska konserwatywnego. I choć intuicja/wiedza podpowiada, że być może wiara w możliwość odkrycia/dotarcia do prawdy, w takim sensie jak to ma miejsce w postawie pierwszej, nie do końca da się pogodzić z rzeczywistymi/realnymi funkcjami pełnionymi przez historię - np.: legitymacyjna czy waloryzacyjna ${ }^{8}$ - to jednak warto znaleźć inne uzasadnienie dla konieczności poznawania przeszłości lub w inny sposób zdefiniować samą kategorię prawdy. Z jednej strony pojawiają się za-

7 Por. M. Woźniak, op. cit.

8 Zob. np. J. Pomorski, Społeczna funkcja historii-analiza kontekstów znaczeniowych pojęcia, w: Społeczna funkcja historii a wspótczesność, red. Z. Mańkowski, J. Pomorski, Lublin 1985. 
tem pojęcia/kategorie uczciwości, odpowiedzialności, sprawiedliwości, z drugiej zaś prawdę odnosi się nie do jakiejś enigmatycznej, a w pewnym sensie i retorycznej „przeszłej rzeczywistości”, ale raczej do konstytuowanego przez historyka/badacza jej obrazu. Kluczowa jednak pozostaje $\mathrm{w}$ dalszym ciągu jej zgodność, choć tym razem nie jest ona odnoszona do odbijającego przeszłość (lub jej fragment) źródła (historycznego), ale doświadczenia/matrycy kulturowej/paradygmatu historiograficznego. Samo źródło, lub może lepiej jego zgodność z „rzeczywistością", jest odnoszone do pewnego lokalnego i historycznie zmiennego kontekstu kulturowego wyrażanego najczęściej w kategoriach doświadczania/przeżywania/postrzegania.

Krzysztof Zamorski jakiś czas temu pisał, że „historia nie jest już wyłącznie nauką o dziejach - jest formą ich uobecniania w teraźniejszości" ${ }^{\prime \prime}$. Przeszłą rzeczywistość nazywa dziwnq - „bo przecież była, ale stale obecną", w tym sensie przynajmniej, że ciągle na nowo powoływaną do życia przez historyków: „Słowo ma moc kreującą rzeczywistość również (a może przede wszystkim) i w tym sensie, że przywołuje przeszłość, odtwarza ją na nowo, uobecnia"10. Jest przy tym oczywiste, że ową „obecność" można pojmować także m.in. jako stały wpływ przeszłości na teraźniejszość w tym sensie, że geneza teraźniejszości czy też jej źródła leżą w przeszłości. Przykładowo można uznać - i to niezależnie od tego czy ta teza ma wystarczające umocowanie - że nasza teraźniejsza sytuacja polityczna bądź gospodarcza jest konsekwencją pewnej umowy między opozycją i władzą podczas rozmów tzw. okrągłego stołu, a w tym sensie przeszłość (ustalenia) kształtuje teraźniejszość (sytuację polityczno-gospodarczą). I, co więcej, w teraźniejszości stosunkowo łatwo można odnaleźć ślady tej przeszłości (np. konkretne rozwiązania prawne czy społeczne zapisane w aktach prawnych). Być może najważniejszą konkluzją tezy K. Zamorskiego jest fakt, że - oczywiście obok alternatywnych jej interpretacji - za „przeszłą rzeczywistość”, a ostatecznie i za kryterium czy punkt odniesienia dla obrazów przeszłości formułowanych przez historyków, określających ich 'prawdziwość' lub 'fałszywość', można uznać (więcej: często się uznaje) nasze aktualne jej 'wyobrażenia', 'reprezentacje' czy sposoby 'uobecniania'. To one, jak można sądzić, kryją się za rozstrzygnięciami zawartymi w klasycznej formule definiującej kategorię prawdy. W efekcie o prawdzie - w sensie zgodności z jakąś zewnętrzną instancją - lub fałszu rozstrzyga 'rzeczywistość' (a w zasadzie jej wyobrażenie lub

9 K. Zamorski, Dziwna rzeczywistość, Kraków 2008, s. 8.

10 Ibidem, s. 9, 20. 
pewna intuicja) uobecniona/zakorzeniona 'tu i teraz', a nie w przeszłości ${ }^{11}$.

W postawie pierwszej - jak pamiętamy - zakorzenionej/opartej na klasycznym ideale nauki historycznej kryterium owej zgodności było/jest umocowane w źródle (historycznym) - obraz przeszłości jest 'prawdziwy', jeśli zgadza się z materiałem źródłowym (jeśli on został uznany za wiarygodny), ale pociągało/pociąga to za sobą konieczność uznania (czy wpisania się w konwencję) określonej koncepcji źródła historycznego, w świetle której 'źródło' rozpoznaje się jako fragment, odbicie czy cząstkę minionego świata (przeszłości/przeszłej rzeczywistości), a nie - przykładowo - odbiciem horyzontów poznawczych (świadomości, poglądów czy wizji świata i człowieka) autora.

Postawa liberalna natomiast pociąga za sobą przekonanie, które najprościej wyrazić w może nieco kolokwialnej, ale niezwykle atrakcyjnej (przynajmniej z punktu widzenia retoryki) formule, która mówi, że $\mathrm{Na}$ każda rzecz można patrzeć z dwóch stron. Jest prawda czasów, o których mówimy i prawda ekranu, która mówi: „Prasłowiańska grusza chroni w swych konarach plebejskiego uciekiniera". W takiej perspektywie jest ona zatem nie tyle „prawdą czasów, o których mówimy”, ale przede wszystkim "prawdą czasów, w których mówimy". Kwestią fundamentalną w tym przypadku stają się jej (prawdy) relacje ze światem wartości (ale także samą historiografia/przeszłością), a zatem próby odpowiedzi na pytanie o to, czy prawdę traktować jako wartość, którą można odnaleźć w pisarstwie/przedsięwzięciu historycznym i która w efekcie determinuje przedsięwzięcie poznawcze (i jego efekty/obrazy przeszłości) obecne/zapisane w ramach dyscypliny, czy raczej jako argument i uzasadnienie dla działalności historyków. W konsekwencji można uznać, że przedmiotem dyskusji nie jest próba rozstrzygnięcia (jeśli jest ono w ogóle możliwe) czy jest (możliwa) jakaś 'prawda historyczna', ale raczej poszukiwanie odpowiedzi na pytanie jak owa 'prawda historyczna' jest obecna w dyskursie/narracji lub szerzej w procesach poznawania przeszłości, i na ile istotną rolę odgrywają w niej aksjologiczne przesłanki (zapisane w teraźniejszości) ${ }^{12}$.

Postawa trzecia wreszcie, której możemy przykleić etykietę pragmatycznej, z góry zakłada, bądź pragmatycznie konstatuje, że kategoria prawdy, podobnie jak inne wartości obecne w dyskursie historycznym lub z nim łączone, stanowią jedynie przesłanki retorycznej argumentacji służącej przekonaniu/perswadowaniu określonego wizerunku prze-

\footnotetext{
11 Por. M. Woźniak, op. cit.

12 Por. ibidem.
} 
szłości, a w konsekwencji podejmowaniu określonych decyzji/działań (tu i teraz). Dostrzega ona (wprawdzie), że historia/historiografia pełni określone funkcje społeczne - te klasyczne/deklarowane (nauczycielka życia, tradycja, tożsamość, integracja, socjalizacja) i te rzeczywiste/realne (legitymacja, waloryzacja) - ale jednocześnie identyfikuje je, zazwyczaj przypisując im konotację negatywną, bo niemającą wiele wspólnego z poznaniem (naukowym), jako narzędzia inżynierii społecznej. W efekcie prawda i jej podobne wartości obecne w dyskursie historycznym okazują się wyłącznie argumentem retorycznym, narzędziem narzucania określonej wizji świata i człowieka, niezbędnym co prawda w sytuacji, gdy podejmowane są próby manipulowania i promowania określonych wartości, ale niepotrzebnym - lub przynajmniej niekoniecznym - a przy okazji niemożliwym, jeśli uzna się, że poznanie historyczne jest jedynie przedsięwzięciem intelektualnym, a nie aktywnościa/projektem o charakterze naukowym. W postawie tej zatem przeszłość/przeszła rzeczywistość jest jedynie pretekstem do myślowej/intelektualnej rozrywki, w najlepszym przypadku służącej ćwiczeniu/treningowi pamięci bądź rozwijaniu wyobraźni (niekoniecznie historycznej). Punkt odniesienia (weryfikacji), a zatem przedmiot poznania ${ }^{13}$ (historycznego) - przeszłość - nie istnieje, więc nie ma potrzeby (i możliwości) umieszczania wśród celów tego typu działalności kategorii prawdy. Źródła historyczne w ramach tego stanowiska dostarczają nam informacji nie tyle o przeszłości, a z pewnością jej nie odbijaja/odzwierciedlają ile raczej o ich autorze/ autorach, ich przesądach, doświadczeniach, przeświadczeniach czy przyzwyczajeniach. Jan Pomorski pisze, że pytania o prawdę w takiej sytuacji - w takiej/podobnej koncepcji źródła - mijają się z celem, gdyż można co najwyżej pytać o ich zgodność (źródeł) ze standardem kulturowym aktualnym dla danej epoki/ich autora ${ }^{14}$.

Paradoksalnie, w ramach tego stanowiska rezygnacja $\mathrm{z}$ wartości przypisywanych zazwyczaj dyskursowi historycznemu/historiografii nie ma charakteru programowego. Traktuje się je raczej pragmatycznie/utylitarnie - żeby nie powiedzieć instrumentalnie - z pełną (samo)świadomością dążąc do realizacji zakładanych zadań/funkcji (społecznych) przypisywanych zazwyczaj historii. Ich zmienność/arbitralność wynika wprost z przyjmowanych założeń i jest zależna od aktualnych potrzeb. W przeciwieństwie do postawy konserwatywnej i liberalnej, realizacja funkcji społecznych, pociągająca za sobą konieczność użycia wartości (prawdy),

${ }^{13}$ Zob. np. J. Pomorski, Historyk i metodologia, szkic trzeci.

14 Idem, Historiografia jako autorefleksja kultury poznającej, w: Świat historii, red. W. Wrzosek, Poznań 1998. 
nie jest jedynie deklaratywna, jak to czasem zdarza się w przypadku dwu pierwszych stanowisk, ale staje się celem samym w sobie/dla siebie i wymaga zazwyczaj odsłonięcia/ujawnienia przed czytelnikiem.

Przyglądając się postawie pierwszej, możemy odnotować w tym miejscu - nieco upraszczając problem - iż prawdy/wartości szuka się/odkrywal dochodzi do. Są traktowane z jednej strony jako składnik świata badanego, z drugiej zaś jako cel przedsięwzięcia historyka. W konsekwencji - nieco paradoksalnie - niektóre wartości traktowane/postrzegane są jako niezbywalny komponent rzeczywistości/świata/historiografii/historii, inne natomiast - przypisywane zazwyczaj historykowi (takie jak: rzetelność, szczerość, obiektywizm, krytycyzm czy wreszcie odwaga) - umożliwiają dotarcie do nich lub są postrzegane jako warunek ich osiągnięcia (wartości stają się celem, ale także drogą do jego osiągnięcia), przez co celem samym w sobie staje się ich realizacja/konkretyzacja.

W postawie drugiej wartości/prawdy są wybierane/wskazywane $\mathrm{z}$ dostępnych $\mathrm{w}$ ramach kultury - ale nie ulega wątpliwości, że ich wybór, choć w gruncie rzeczy arbitralny, odczytywany jest w kategoriach zgodności z obowiązującym standardem kulturowym, a w tym sensie traktowany jako zobiektywizowany i w pewien sposób naturalny/neutralny. Zmienność/wybieralność wartości przypisywanych historii/historiografii nie zmienia faktu, że u podstaw tego stanowiska leży wiara/przeświadczenie/założenie o istotnej roli wartości obecnych/przypisywanych tak wizerunkom przeszłości (aksjologicznej warstwie narracji historycznej), jak i ich twórcom. Choć w tym przypadku już nie chodzi jedynie o ich realizację/konkretyzację, ale bardziej o identyfikację.

W postawie trzeciej natomiast, jeśli nie ucieka się od wartości w ogóle, to próbuje się je kreować/konstytuować lub arbitralnie wskazywać/propagować jako te najbardziej uniwersalne czy pożądane (tu i teraz). O ile w postawie pierwszej gwarantem (ale i źródłem) prawd/wartości stają się świadectwa/dowody oraz warsztat (historyka), a w drugiej paradygmat, o tyle charakterystyczne dla stanowiska trzeciego jest to, że źródeł wartości/prawd i ich gwarancji poszukuje się w sferze ich (aktualnej) użyteczności/skuteczności.

Nie ulega przy tym wątpliwości, że mimo bardziej lub mniej fundamentalnych różnic, które możemy dostrzec $\mathrm{w}$ poszczególnych postawach, łączy je - choć różne mogą być w tym przypadku intencje - wiara w moc autorytetu (źródła/teorii/znanego/wpływowego badacza), bo to on w rzeczywistości/ostatecznie określa wartość przypisywaną historii/historiografii. Odwaga, rzetelność, krytyczność, obiektywizm - wyrażane często 
$\mathrm{w}$ bardziej opisowych formułach typu: nikt o tym nie pisat; wypetnia białe plamy historii; walczy z mitami/stereotypami/nieprawda; rzuca nowe światło to z kolei podstawowe kategorie, charakterystyczne dla wszystkich tych stanowisk, służące ocenie i wartościowaniu dorobku badaczy przeszłości (przynajmniej z tych wyrażanych $\mathrm{w}$ recenzjach), które stają się $\mathrm{w}$ takim przypadku jednocześnie miarą tych wartości. Nie zmienia to oczywiście faktu - czego doświadczamy na co dzień - że we współczesnym/naszym świecie akademickim, przynajmniej z punktu widzenia „czynników parametryzacyjnych”, miarą wartości (badacza i jego dorobku) stają się punkty, cytowania, indeksy, wskaźniki...

Powyższe obserwacje wydają się istotne przede wszystkim dlatego, że możliwe rozstrzygnięcia dokonywane $\mathrm{w}$ ramach wymienionych postaw/stanowisk przesądzają lub mogą przesądzać o dostrzeganym/formułowanym w danej teraźniejszości sensie dziejów (historii), a ostatecznie zatem także sensie poszczególnych przywoływanych przez dyskurs historyczny wydarzeń i zjawisk historycznych. Uznanie prób wyjaśnienia (wydarzeń z) przeszłości za kluczowy komponent badań historycznych (poznania) sprawia, że nie można pominąć milczeniem faktu, iż dostrzegany/konstytuowany - i zazwyczaj łączony z kategorią prawdy lub za jej pomocą wyrażany - w dziejach porządek czy (ogólny) sens determinuje (a przynajmniej może to czynić) próby odpowiedzi na pytanie dlaczego? odnoszące się do konkretnych zjawisk i wydarzeń. Można uznać np., że wyjaśnienie - próba odpowiedzi na pytanie - dlaczego doszło do rozbiorów I Rzeczypospolitej może odwoływać się do bardziej ogólnego pytania o rolę/znaczenie Polski w dziejach. Mesjanistyczna wizja przeszłości - wciąż przecież obecna w naszym myśleniu - może kazać nam postrzegać to wydarzenie jako swego rodzaju karę za 'grzechy' (zaniedbania), która ma prowadzić do 'uzdrowienia' (odrodzenia). Można zatem dostrzec, że ogólny sens przypisywany dziejom uczestniczy w odpowiedziach na pytania szczegółowe (dotyczące konkretnych wydarzeń czy zjawisk). W efekcie trudno oprzeć się wrażeniu, że prawda umocowana $\mathrm{w}$ świecie wartości przesądza o aksjologicznych przesłankach nie tylko możliwych do dostrzeżenia sensów/znaczeń dziejów jako całości, ale i partykularnych ich (dziejów) elementów. W efekcie to wartości, a nie procedury poznawcze czy warsztat, określaja/determinują możliwe próby wyjaśnień (tego co było $)^{15}$.

15 Por. M. Woźniak, op. cit. 
Jeśli zatem to prawda/wartości determinuje/ą sensy dziejów - przypisywane dziejom znaczenia - to dostrzegając jej/ich aksjologiczną genezę nietrudno wywnioskować, że obrazy przeszłości są efektem nie tyle (lub nie tylko) procedur poznawczych, ale także (lub przede wszystkim) wyznawanych przez ich animatorów wartości lub wartości kultury, która te wartości kreuje/narzuca. I nie zmienia aktualności tego twierdzenia także sytuacja, w której uznajemy, że to nie prawda narzuca sensy/znaczenia, ale iż jest ona ich konsekwencją. Jest bowiem oczywiste, że przypisywane dziejom (bądź w nich dostrzegane) znaczenia (ogólne i szczegółowe) nie pozostają wolne od aksjologicznych przesłanek. Nie można bowiem przejść obojętnie wobec faktu, że są one warunkowane, żeby nie powiedzieć determinowane i podporządkowane naszym wyobrażeniom, związanym z próbami określenia celu dziejów, a w konsekwencji także podejmowanym co jakiś czas próbom przepowiedzenia przyszłości. Stają się ostatecznie bardziej wyrazem naszych nadziei, oczekiwań czy trosk niż procedur poznawczych, w tym sensie przynajmniej, że wiążą się z próbami zmiany negatywnych zjawisk - bądź tak klasyfikowanych - obecnych „tu i teraz". Próby te nie muszą oczywiście być rezultatem (naukowego) namysłu czy diagnozy, ale wynikać z naszych oczekiwań wobec przyszłości. W takiej perspektywie na XIX-wieczne próby odzyskania suwerenności (powstania) można - a w zasadzie należy - patrzeć, nie jako na konsekwencje naukowego odczytania trendów czy logiki dziejów, ale jako na pragnienie realizacji pożądanych przez ich uczestników wartości.

Zakończę optymistycznie: można by, jak się wydaje zasadnie, pytać o to, po co nam w ogóle prawda/wartości w historii/historiografii? Z przedstawionych wyżej - może nieco powierzchownych, ale ciągle aktualizowanych i potwierdzanych w naszej codzienności („dobra zmiana w historii") - obserwacji wynika bowiem, przynajmniej w jednej z możliwych interpretacji, że prawda/prawdy/wartości okazują się w zasadzie retorycznymi argumentami wykorzystywanymi w sporach między konkurencyjnymi wizjami/wizerunkami przeszłości/świata. Ich rolę/funkcje sprowadza się lub sprowadzić można do umacniania/kreowania autorytetu Historyka (nie historia, a historyk osądzi...), a w konsekwencji do prowadzenia (właściwej) polityki historycznej. Polityki służącej z jednej strony konstytuowaniu (pożądanej) pamięci (historycznej) oraz budowie (narodowej) tożsamości/świadomości, z drugiej zaś integracji/konsolidacji - a w pewnym sensie także specyficznej formie socjalizacji - członków społeczności wokół propagowanych/lansowanych toposów, ideałów, wzorców. Służącej zatem nie jedynie budowie/konstytuowaniu "człowieka historycznego" - w sensie nadawania/narzucania mu określonego dziedzictwa (z) przeszłości - ale przede wszystkim projektowaniu 
pożądanych postaw, wskazywaniu możliwych wyborów czy wreszcie podejmowaniu określonych decyzji/działań. Można się oczywiście zastanawiać, czy potrzebujemy do tego „historii prawdziwej”? Wydaje się bowiem, że to właśnie wiara w prawdę/prawdy (historyczne), a w zasadzie w kryjącą się za tego typu wartościami (paradoksalnie za ich obecnością, ale i nieobecnością) moc, pozwala, a pewnym sensie także każe, instrumentalizować historię/historiografię i kryjące się za nimi lub przypisywane im wartości. Pytanie tylko - retoryczne chyba w swej naturze - czy od owych prawd/wartości można uciec? Lub czy powinniśmy od nich uciekać? Czy bez nich możliwa byłaby historia/historiografia, a nawet szerzej: kultura? Trywializując nieco postawy i wynikające z nich konsekwencje scharakteryzowane powyżej - przypomnijmy: 1) nie ma prawdy? prawda jest i tyle...; 2) nie ma prawdy? - trudno, po co nam prawda...; 3) nie ma prawdy? - wykreujemy naszą... - uznajmy zatem - nie wprost udzielając odpowiedzi na te z natury retoryczne pytania - że identyfikując z kulturą wartości (w tym prawdę/prawdy), a w konsekwencji także oparte na nich obrazy/wyobrażenia przeszłości, ucieczka od prawd/wartości, podobnie jak od kultury, która je konstytuuje, jest/byłaby nie tylko szkodliwa i niepotrzebna, ale i niemożliwa. Zdając sobie sprawę z uwikłania poznania historycznego (i wartości) w kulturę, uznajmy, że tak jak nie można bowiem uciec od kultury, tak nie można uciec i od wartości/ prawdy/prawd. A ostatecznie: po co (byłaby) nam historia/historiografia bez prawdy/prawd/wartości...(?).

\section{BIBLIOGRAFIA (REFERENCES)}

Pomorski J., Historiografia jako autorefleksja kultury poznajacej, w: Świat historii, red. W. Wrzosek, Poznań 1998.

Pomorski J., Historyk i metodologia, Lublin 1991.

Pomorski J., Społeczna funkcja historii - analiza kontekstów znaczeniowych pojęcia, w: Społeczna funkcja historii a wospółczesność, red. Z. Mańkowski, J. Pomorski, Lublin 1985.

Stobiecki R., Historia pod nadzorem: spory o nowy model historii w Polsce (II połowa lat czterdziestych - poczatek lat pięćdziesiatych), Łódź 1993.

Valéry P., Regards sur le monde actuel, Paris 1931.

Woźniak M., Od prawdy historycznej do sensu dziejów. Wartości a obraz przeszłości, w: Aksjologiczne aspekty dyskursu humanistycznego, Chełm 2012.

Zamorski K., Dziwna rzeczywistość, Kraków 2008. 


\section{ABSTRACT}

In the article, I try to answer questions about the role/functions of values in historical writing, about their place in the narrative, and I wonder whether historiography free from (historical) truth is at all possible. I assume, referring primarily to the sociology of knowledge and tools offered by the constructivist model of cognition, that the position regarding truth/value in historical research is realised in three (at least) attitudes, namely conservative, liberal and pragmatic. The superstitions present in each of them determine the attitude to truth/values and their functions in cognitive processes. The observations presented in the article show that the truth/truths/values turn out to be essentially rhetorical arguments used in disputes between competing visions/images of the past/the world. Their functions come down to strengthening/creating the authority of the Historian and, consequently, to conducting a (proper) historical policy.

Key words: truth, values, historiography, historical research, research process, the ideal/model of historical science

\section{NOTA O AUTORZE}

Marek Woźniak - doktor habilitowany, profesor UMCS, pracuje w Zakładzie Metodologii Historii Instytutu Historii Uniwersytetu Marii Curie-Skłodowskiej w Lublinie. Jego zainteresowania naukowe i tematyka badawcza to: kulturowy wymiar badań historycznych, współczesna refleksja nad pisarstwem historycznym, pamięć i wyobraźnia historyczna w refleksji nad badaniem przeszłości, sposoby doświadczania przeszłości, polityka historyczna, kulturowy i społeczny wymiar mitu historycznego, metodologia historii, historia historiografii. Ważniejsze publikacje: Doświadczanie historii. Kulturowy i społeczny wymiar mitu rewolucji (Lublin 2003); Przeszłość jako przedmiot konstrukcji. O roli wyobraźni w badaniach historycznych (Lublin 2010); Świat z historia (wespół z Piotrem Witkiem) (Lublin 2010); Niezrealizowane drogi historii (redakcja) (Lublin 2012); Historia w kontekstach nieoczekiwanych (wespół z Ewą Solską i P. Witkiem) (Lublin 2016); Historie alternatywne i kontrfaktyczne (wespół z E. Solską i P. Witkiem) (Lublin 2017); Między nauka a sztuka wokót problemów wspótczesnej historiografii (wespół z E. Solską i P. Witkiem) (Lublin 2017). E-mail: wozmar@poczta.fm 